\title{
Language Platforms and the Internationalization of Cultural Industry
}

\author{
Wenqiu Zhang \\ School of Business, Nanjing Normal University, Nanjing, China \\ Email: slwenqiu@aliyun.com
}

How to cite this paper: Zhang, W.Q. (2019) Language Platforms and the Internationalization of Cultural Industry. Open Journal of Social Sciences, 7, 114-124. https://doi.org/10.4236/jss.2019.77011

Received: June 12, 2019

Accepted: July 16, 2019

Published: July 19, 2019

Copyright $\odot 2019$ by author(s) and Scientific Research Publishing Inc. This work is licensed under the Creative Commons Attribution International License (CC BY 4.0).

http://creativecommons.org/licenses/by/4.0/

\section{c) (i) Open Access}

\begin{abstract}
This article focuses on the relationship between the language platforms and the internationalization of cultural industry based on the panel data from 1995 to 2016 in 43 countries. The result shows that by substituting the negative effect because of the culture distance, Confucius Institutes can significantly promote the internationalization of Chinese cultural industry and the promotional effects show dissimilarities. The promotional effects are stronger in countries with closer culture. In Asia, Europe and South America setting Confucius Institutes can promote the export of cultural products better than in other continents. The article suggests the enterprises concerned should pay more attention to the promotional effects of the International language learning platform when they choose international target markets for the cultural products.
\end{abstract}

\section{Keywords}

Language Platforms, The Internationalization of Cultural Products, Culture

Distance, Gravity Model of Trade

\section{Introduction}

In the process of "going global", the enterprises should choose "where to go" and "how to go". In 2016, the foreign direct investment of Chinese culture/sports and entertainment industry totaled US $\$ 8.12$ billion, accounting for only $0.5 \%$ of China's foreign direct investment stock. Meanwhile the export volume of Chinese cultural products has reached a level. Exporting cultural products is the main method for Chinese cultural industry "going global". Cultural trade is also an important means of the internationalization of cultural industries in developed countries, and it plays an important role in their international trade. In contrast, the overall level of China's cultural trade is not high, the export compe- 
titiveness and the influence of cultural products in the international market are weaker than developed countries, and the export duration is generally far from the developed countries. In the context of transformation and upgrading of China economic structural, it is necessary to promote the export of cultural products and optimize the location choice of cultural enterprises in the process of internationalization.

Communication and mutual authentication are the essential requirement of the development of civilization. As a language learning platform to promote Chinese language and Chinese traditional culture to "go global", Confucius Institute has been operated around the world [1]. Till the end of 2016, there have been 1638 Confucius Institutes in 140 countries (regions). They not only promoted China's education exports, but also significantly promoted foreign direct investment, which is conducive to bilateral trade. Due to the cultural characteristic of cultural products, they are vulnerable to the negative impact of cultural barriers in the process of export trade. Therefore, while promoting cultural exchanges, whether the construction of language learning platforms can promote the export of Chinese cultural products and the internationalization of the Chinese cultural industry, is worth studying and discussing.

\section{Literature Review and Impact Mechanism Analysis}

\subsection{Literature Review}

Scholars' researches on the internationalization of cultural industries are mainly focused on the export of cultural products. The export of products in the cultural industry is different from the international trade of general commodities. It has both commodity attributes and cultural attributes. Scholars study the factors that influence the cultural trade from two aspects: "economic factors" and "non-economic factors" correspond to the "double attributes" of cultural products.

In general, cultural products exports are consistent with overall commodity export trade trends, and this fact shows the commodity attributes of cultural products. A large number of mature studies have focused on the significant impact of "economic factors" on the export of cultural products, including the level of economic development of both countries: the market size and market potential of the host country, labor productivity, and trade openness: trade preferential policies, free trade zone and free trade agreement arrangements, customs duties and import clearance time [2]. The traditional geographical distance factor has a great impact on the cost of cultural trade. However, with the upgrading of the global logistics system, the negative impact of the transportation cost caused by geographical distance on the internationalization of cultural products is gradually decreasing [3].

Due to the particularity of cultural products, the influence of culture as an informal institutional factor on cultural trade has gradually attracted the scholars' attention. Scholars generally believe that higher language familiarity or similarity 
[4], common religious beliefs [5], colonial relations or similar colonial history are conducive to the development of cultural trade [6]. Scholars often use the cultural distance indicator to measure the cultural differences between the two countries. Researches show that cultural differences will increase the international operating costs of enterprises, which is not conducive to the export of cultural products in general. Therefore, scholars believe that we should pay attention to the negative impact of cultural discounts and carry out effective measures for example cultural diplomacy, to promote the spread of Chinese culture [2].

Since going global strategy was formally put forward in 2000, the government has not only encouraged Chinese enterprises to "go global", but also emphasized traditional culture to "going global" and promoting the world's understanding of traditional Chinese culture through the construction of language learning platforms. The Confucius Institute is one of the most important windows for cultural exchanges between China and foreign countries. At present, the researches on Confucius Institutes are mostly based on the establishment significance, development problems, and the influence on goods trade and OFDI. Scholars believe that Confucius institutes are conducive to the promotion of Chinese language and provide opportunities for other countries to understand Chinese culture. Lian Daxiang (2014), Xie Mengjun et al. (2017) found that the establishment of Confucius institutes is conducive to China's export trade and the development of OFDI [7] [8]. An Yalun et al. (2006) believe that, to some extent, the cultural transmission effect of Confucius institutes can enhance the sense of identity of trading partners to traditional Chinese culture, thus contributing to the "going global" of China's cultural industry [9].

From the existing research results, scholars' researches on the internationalization of Chinese cultural industry focus on the selection and confirmation of influencing factors. As an important part of informal system, culture has also attracted some scholars' attention. They mainly start from the impact of cultural transaction costs caused by cultural differences between countries on trade, and analyze their mechanism and effect. However, the influence and mechanism of the government on the international operation of cultural industry in promoting cultural exchange have not been fully studied.

Therefore, based on the background of civilized exchanges and mutual learning, this paper takes the panel data of China's exports of cultural products from 43 countries in 1995-2017 as a sample, and uses the trade gravity model to focus on the possible influence of Confucius Institutes on the Internationalization of Chinese cultural industry, and explore the interaction between cultural differences and cultural communication caused by Confucius Institutes when comes to the cultural trade.

\subsection{Analysis of the Mechanism of Language Learning Platform Affecting the Internationalization of Cultural Industry}

Generally speaking, cultural products have relatively distinct cultural characte- 
ristics. If the cultural differences between the two countries are greater, the more unfavorable the cultural trade between the two countries is concerned; if the two countries are culturally closed, cultural identity and similar cultural consumption preferences will promote cultural trade. By combing the relevant literature, it can be found that cultural exchange can promote the development of Chinese cultural products export trade through the transaction cost reduction effect path.

The transaction costs arising from cultural differences are not conducive to the export trade of cultural products. In the process of enterprise internationalization, due to the geographical distance, the trading country needs to bear the transportation cost; similarly, the cultural distance invisible due to cultural differences between countries also requires the trading country to pay the cultural transaction cost. The similarity of languages reduces the cost of language transactions in the process of internationalization of the cultural industry. Language similarity can reduce agency costs in the process of information dissemination. The Chinese language promotion function of Confucius institutes is conducive to reducing communication costs and information asymmetry barriers, and promoting the development of export trade. In recent years, with the increase in the number of students learning Chinese, the number of teachers sent by Hanban to the Confucius Institutes has also increased providing a convenient channel for foreigners to learn Chinese. The increasing international influence of Chinese language is, to a certain extent, conducive to promoting relevant cultural enterprises to "go global".

\section{Models, Variables and Data}

\subsection{Model Setting and Description}

This paper will build a measurement model with Chinese cultural products as the dependent variable, language learning platform as the core explanatory variable, and other factors between China and the host country as the control variables. This paper draws on the trade gravitational model commonly used in the existing literature to construct the following benchmarking model:

$$
\begin{aligned}
\mathrm{LnCV}_{i t} & =\beta_{0}+\beta_{1} \mathrm{If}_{-} \mathrm{AC}_{i t}+\beta_{2} \mathrm{LnGDP}_{i t}+\beta_{3} \mathrm{CD}_{i t}+\beta_{4} \operatorname{LnDS}_{i t} \\
& +\beta_{5} \mathrm{EF}_{i t}+\beta_{6} \mathrm{VISIT}_{i t}+\lambda_{t}+\mu_{i}+\varepsilon_{i t} \\
\mathrm{LnCV}_{i t} & =\beta_{0}+\beta_{1} \mathrm{LnAC}_{i t}+\beta_{2} \mathrm{LnGDP}_{i t}+\beta_{3} \mathrm{CD}_{i t}+\beta_{4} \mathrm{LnDS}_{i t} \\
& +\beta_{5} \mathrm{EF}_{i t}+\beta_{6} \mathrm{VISIT}_{i t}+\lambda_{t}+\mu_{i}+\varepsilon_{i t}
\end{aligned}
$$

Among them Ln represents the logarithm, $i$ and $t$ represent the country and the year. $\mathrm{CV}_{i t}$ represents the export volume of cultural products from China to country (region) $i$ in year $t$. As the core explanatory variable, $\mathrm{AC}_{i t}$ indicates the number of applications for the establishment of Confucius Institutes by country (region) $i$ to Hanban in year $t$. $\lambda_{t}$ means time fixed effects, $\mu_{i}$ means country fixed effects, $\varepsilon_{i t}$ is a random error term. Model (1) examines the amount of language learning platform on the export of Chinese cultural products; model (2) examines whether the policy that establish language learning platforms in the 
host country has an impact on the internationalization of Chinese cultural industry.

\subsection{Sample Selection}

In order to fully study the impact of the establishment and scale of language learning platforms on the internationalization of cultural industry, this paper chooses the Confucius Institute as the core explanatory variable. Since the Confucius Institute was only established in 2004, the statistical bulletin of the Confucius Institute has been published since 2006 by Hanban. Scholars have chosen samples after 2006, but lacked research on the differences between them. Therefore, the survey period selected in this paper is from 1995 to 2017. Taking the export panel data of China's core cultural products as a sample, considering the availability of relevant data, the final sample of this study is 43 host countries. ${ }^{1}$

\subsection{Variable Description and Data Source}

This paper mainly examines the impact of language learning platforms on the internationalization of Chinese cultural industries. According to the selected model, this paper takes the export value of China's core cultural products as the explanatory variable, and the Confucius Institute, which represents the language learning platform, as the core explanatory variable. The Control variables are divided into five aspects: economic, cultural, geographical, political and diplomatic. The meaning of each variable and the data source are as follows.

1) Explained variable.

This article takes China's core cultural product exports value (CV) to each host country as an explanatory variable, and the data comes from the UNComtrade Statistics Database. According to the classification of core cultural products in the UNESCO Cultural Statistics Framework, the author finds the top 2 HS six-digit code of the corresponding products in the HS2002 version, and sorts out the export data of Chinese cultural products from 1995 to 2017.

2) Explanatory variables.

As more and more foreign people learn Chinese language, Confucius Institutes are playing an important role in this progress. So the paper chooses the amount of Confucius Institutes as the core explanatory variable representing the language learning platform (AC). The number of Confucius Institutes that applied by universities in the host countries cooperating with Hanban is based on the annual Confucius Institute Annual Development Report published by Hanban. In order to investigate the impact of the establishment of the Confucius Institute on the export of Chinese cultural products, add a dummy variable

${ }^{1}$ The 43 samples studied in this paper include: Argentina, Brazil, Peru, Chile, Colombia (5 South American sample countries); Canada, Mexico, the United States (3 North American sample countries); Japan, Korea, Malaysia, Hong Kong, India, Indonesia, Philippines, Singapore, Saudi Arabia, Thailand, Iran, Vietnam (12 Asian countries or regions); Austria, Belgium, Czech Republic, Denmark, Finland, France, Germany, Greece, Italy, Netherlands, Norway, Poland, Portugal, Russia Spain, Sweden, Switzerland, Turkey, United Kingdom (19 European sample countries); Egypt, Nigeria (2 African country countries); Australia, New Zealand (2 countries in Oceania sample countries). 
If _ $\mathrm{AC}_{i t}$ to the model. If a country (region) applies to Hanban for the establishment of a Confucius Institute in the year $t$, the value is 1 , otherwise the value is 0 . Therefore the variable If $\_\mathrm{AC}_{i t}$ in the above model (2) is actually equivalent to the product of the experimental group and the control group in the single-time point DID model. Therefore, the influence of the construction of the Confucius Institute on the internationalization of cultural enterprises shows from the coefficient $\beta_{1}$ of variable If $\mathrm{AC}_{i t}$.

3) Control variables.

a) Market size (GDP). It is expressed in terms of gross domestic product during the inspection period of the host country (region), and the data is derived from the United Nations Statistics Office database.

b) Cultural differences (CD). Scholars often use the cultural distance indicator to quantify cultural differences and propose a measurement model of cultural distance from different dimensions. The cultural distance measure formula proposed by Kogut (1988) and Hofstede (2010) [10] [11]. Since Hofstede's international cultural dimension index has not been updated year by year, scholars often assume that cultural differences between countries do not change with time, which is inconsistent with the reality of cultural exchanges. The data of each cultural dimension comes from the official website of Hofstede. The establishment of diplomatic relations was from the official website of the Chinese Ministry of Foreign Affairs (Hong Kong adopted 1997 as the base year).

c) Geographic distance (DS). DS is geographic distance from China's Beijing to the capitals (administrative centers) of the sample countries (regions), which indicates the impact of geographic distance on export costs. The data is derived from the CEPII database.

d) Institutional quality (EF). This article uses the Index of Economic Freedom published by The Heritage Foundation to measure the level of institutional quality in the host country (region). When adopting this indicator, scholars generally think that the greater the economic freedom index is, the better the system quality will be.

e) The number of state visits (VISIT). The exchange of state affairs between the leaders of the two countries is conducive to promoting political exchanges and building good political relations. The indicator is based on the number of Chinese leaders, prime ministers and ministers visiting and receiving the leaders and officers from host countries (regions). The data comes from the website of the Chinese Ministry of Foreign Affairs.

\section{The Analysis of Empirical Results}

\subsection{Model Selection and Inspection}

The correlation coefficient and descriptive statistical results between the variables show that the correlation between the variables is low. The model was determined to be a fixed effect model by a correlation test. Since the geographical distance is fixed in a short period of time, the paper selects the least squares 
virtual variable model, introduces time dummy variables, and uses clustering robust standard errors. The mean value of VIF indicates that there is no serious collinearity problem in the model.

\subsection{Analysis of Total Samples}

In Table 1, Model 1 is the test result of regression estimation only for control variables, and Model 2 introduces whether to establish the virtual variable of Confucius Institute, and whether the establishment of Confucius Institute has an impact on the export of Chinese cultural products; Model 3 introduces the Confucius Institute variables. Further examine the impact of the Confucius Institute on corporate export cultural products.

In Model 2 and Model 3, the establishment of the Confucius Institute and its scale variables passed the $1 \%$ significance test. After joining the Confucius Institute variables, the model can better explain the reasons for the increase in the export volume of Chinese cultural products. The establishment of the Confucius Institute can significantly promote the export of cultural products. And the larger the Confucius Institute, the more favorable it is for the export of cultural products. The overall sample regression results indicate that the establishment and scale of the Confucius Institute has significantly promoted the export of enterprises to cultural products.

From the perspective of other variables, in the Model 1 in which the core explanatory variables were not introduced, the market size of the host country, cultural differences with China, and political influences have a significant impact on China's export cultural products. The significant impact of consumer demand on cultural product trade indicates that the commodity attributes of cultural products, and the inhibition of cultural differences on cultural trade shows the cultural attributes unique to cultural products, which is consistent with the research conclusions of scholars. Compared with the high degree of bilateral political exchange between Model 1 and Model 2, the significance of political relations has declined in Model 3, which was obtained using the Confucius Institute scale variable, indicating that cultural exchanges and political exchanges may be possible for bilateral trade development. It has an interaction facilitation and will be discussed further later. The indicators of economic freedom have a positive impact, but the significance is not high, indicating that the market economy of the host country is highly complete and the local government has fewer restrictions on imported products, which can be beneficial to the import of Chinese cultural products to a certain extent, but the impact of this factor is limited.

\subsection{Sub-Sample Discussion}

According to the sample estimation results in Table 1 \& Table 2, comparing Model 4 and Model 5, it can be seen that due to the influence of cultural differences, the Confucius Institute's promotion effect on cultural trade is heterogeneous. Among the samples with small cultural differences, the Confucius Insti- 
tute's promotion role is more significant; while in the culturally diverse samples, the influence of the Confucius Institute is positive, but it has not passed the significance test, which means that although through the spread of Chinese and foreign cultural exchanges, the Confucius Institute helps to reduce the cultural barriers between the two countries, which hinders the export of Chinese cultural products, but this effect is more pronounced in countries with similar cultures. Mainly because cultural differences are formed in the advancement of history, and the historical start-up and closeness of the cultural exchanges with China in different countries have led to different cultural differences between countries and China. In countries with little cultural differences, Chinese traditional culture is more easily understood and accepted by local consumers; while larger cultural differences are difficult to dissipate in the short term, local consumers have added a sense of strangeness to Chinese culture, which limits the effect of the language learning platform. Then more and more cultural exchange activities that can be more easily accepted by the local people are needed to promote its role.

Table 1. Sample estimation results.

\begin{tabular}{|c|c|c|c|c|c|}
\hline \multirow{2}{*}{ Variable } & \multicolumn{3}{|c|}{ Total sample } & \multicolumn{2}{|c|}{$\begin{array}{l}\text { Grouped by } \\
\text { cultural distance }\end{array}$} \\
\hline & M1 & M2 & M3 & $\begin{array}{c}\text { M4 } \\
\text { Small CD }\end{array}$ & $\begin{array}{c}\text { M5 } \\
\text { Large CD }\end{array}$ \\
\hline IF_AC & & $\begin{array}{c}0.5976^{* * *} \\
(0.1094)\end{array}$ & & & \\
\hline $\operatorname{Ln} A C$ & & & $\begin{array}{l}0.1160^{* * *} \\
(0.0728)\end{array}$ & $\begin{array}{l}0.1498^{* *} \\
(0.0644)\end{array}$ & $\begin{array}{c}0.0845 \\
(0.0583)\end{array}$ \\
\hline LnGDP & $\begin{array}{c}2.3501^{* * *} \\
(0.0802)\end{array}$ & $\begin{array}{c}1.8968^{* * *} \\
(0.1403)\end{array}$ & $\begin{array}{l}2.2502^{* * *} \\
(0.0838)\end{array}$ & $\begin{array}{c}2.0611^{* * *} \\
(01593)\end{array}$ & $\begin{array}{c}2.3361^{* * *} \\
(0.2130)\end{array}$ \\
\hline $\mathrm{CD}$ & $\begin{array}{c}-4.1294^{* * *} \\
(0.1080)\end{array}$ & $\begin{array}{c}-3.9416^{\star * *} \\
(0.4709)\end{array}$ & $\begin{array}{c}-4.0537^{* * *} \\
(0.1116)\end{array}$ & $\begin{array}{c}-14.0186^{*} \\
(7.7467)\end{array}$ & $\begin{array}{c}-3.7795^{\star * *} \\
(0.2865)\end{array}$ \\
\hline LnDS & $\begin{array}{c}0.9491^{* * *} \\
(0.1906)\end{array}$ & $\begin{array}{c}1.0082^{* * *} \\
(0.1084)\end{array}$ & $\begin{array}{l}1.0141^{* * *} \\
(0.1983)\end{array}$ & $\begin{array}{l}-0.0431 \\
(0.0431)\end{array}$ & $\begin{array}{c}0.0049 \\
(0.0403)\end{array}$ \\
\hline $\mathrm{EF}$ & $\begin{array}{c}0.0100 \\
(0.0160)\end{array}$ & $\begin{array}{c}0.0044 \\
(0.0193)\end{array}$ & $\begin{array}{c}0.0074 \\
(0.0167)\end{array}$ & $\begin{array}{l}0.0361^{* *} \\
(0.0171)\end{array}$ & $\begin{array}{l}-0.0095 \\
(0.0307)\end{array}$ \\
\hline VISIT & $\begin{array}{l}0.0191^{* * *} \\
(0.0084)\end{array}$ & $\begin{array}{l}0.0131^{* * *} \\
(0.0042)\end{array}$ & $\begin{array}{l}0.0116^{* *} \\
(0.0081)\end{array}$ & $\begin{array}{l}0.0103^{*} \\
(0.0054)\end{array}$ & $\begin{array}{c}0.0122 \\
(0.0086)\end{array}$ \\
\hline CONS & $\begin{array}{c}-39.8519^{* * *} \\
(2.3789)\end{array}$ & $\begin{array}{c}-28.6202^{\star * *} \\
(3.7175)\end{array}$ & $\begin{array}{c}-37.8174^{* * *} \\
(2.4707)\end{array}$ & $\begin{array}{c}-5.3430 \\
(18.4634)\end{array}$ & $\begin{array}{c}-28.7299^{* * *} \\
(6.2070)\end{array}$ \\
\hline $\mathrm{R} 2$ & 0.8012 & 0.8167 & 0.8050 & 0.8354 & 0.7770 \\
\hline OBS & 946 & 946 & 946 & 396 & 550 \\
\hline
\end{tabular}

a. Note: “*”, “**” and “***” represent significant levels of significance at $10 \%, 5 \%$ and $1 \%$, respectively; data in parentheses are standard errors; obs indicates the number of samples. 
Table 2. Robustness test.

\begin{tabular}{|c|c|c|c|c|}
\hline \multirow[b]{2}{*}{ IF_AC } & \multicolumn{2}{|c|}{$\begin{array}{c}\mathrm{LnCV} \\
\text { (static cultural distance) }\end{array}$} & \multicolumn{2}{|c|}{$\begin{array}{c}\text { LnCV } \\
\text { (mixed effect) }\end{array}$} \\
\hline & $\begin{array}{l}1.4597^{\star * *} \\
(0.1130)\end{array}$ & & $\begin{array}{l}1.4808^{* * *} \\
(0.1114)\end{array}$ & \\
\hline $\operatorname{Ln} A C$ & & $\begin{array}{l}0.3970^{* * *} \\
(0.0729)\end{array}$ & & $\begin{array}{c}0.4093^{\star * *} \\
(0.0767)\end{array}$ \\
\hline LnGDP & $\begin{array}{l}0.7220^{\star * *} \\
(0.0847)\end{array}$ & $\begin{array}{c}0.7334^{\star * *} \\
(0.0839)\end{array}$ & $\begin{array}{l}0.7225^{\star * *} \\
(0.0930)\end{array}$ & $\begin{array}{c}0.7318^{\star * *} \\
(0.0907)\end{array}$ \\
\hline $\mathrm{CD}$ & $\begin{array}{c}-0.3474^{* * *} \\
(0.1072)\end{array}$ & $\begin{array}{c}-0.3567^{\star * *} \\
(0.1117)\end{array}$ & $\begin{array}{c}0.0731 \\
(0.0908)\end{array}$ & $\begin{array}{c}0.0788 \\
(0.0979)\end{array}$ \\
\hline LnDS & $\begin{array}{c}-0.6195^{* * *} \\
(0.1721)\end{array}$ & $\begin{array}{c}-0.6308^{* * *} \\
(0.1984)\end{array}$ & $\begin{array}{c}-1.0645^{* * *} \\
(0.2552)\end{array}$ & $\begin{array}{c}-1.0909^{* * *} \\
(0.2902)\end{array}$ \\
\hline $\mathrm{EF}$ & $\begin{array}{l}0.0343^{\star *} \\
(0.0142)\end{array}$ & $\begin{array}{l}0.0350^{\star *} \\
(0.0167)\end{array}$ & $\begin{array}{c}0.0245 \\
(0.0151)\end{array}$ & $\begin{array}{c}0.0248 \\
(0.0176)\end{array}$ \\
\hline VISIT & $\begin{array}{c}0.0194^{* * *} \\
(0.0066)\end{array}$ & $\begin{array}{c}0.0132 \\
(0.0081)\end{array}$ & $\begin{array}{l}0.0152^{\star *} \\
(0.0070)\end{array}$ & $\begin{array}{c}0.0084 \\
(0.0089)\end{array}$ \\
\hline CONS & $\begin{array}{l}5.0262^{*} \\
(2.6711)\end{array}$ & $\begin{array}{l}5.2458^{* *} \\
(2.4707)\end{array}$ & $\begin{array}{l}8.4833^{* *} \\
(3.2282)\end{array}$ & $\begin{array}{c}8.8851^{\star * *} \\
(2.9817)\end{array}$ \\
\hline $\mathrm{R} 2$ & 0.7338 & 0.6454 & 0.7016 & 0.6117 \\
\hline OBS & 946 & 946 & 946 & 946 \\
\hline
\end{tabular}

\subsection{Analysis of Robustness}

In order to analyze the robustness of the above regression results, on the one hand, on the premise of keeping other variables unchanged, the traditional cultural distance calculation formula is used to replace the cultural distance the mentioned above; on the other hand, the mixed effect is estimated to test the robustness of the results. The results in Table 2 show that under the two test methods, the establishment of the Confucius Institute and its scale variables have passed the $1 \%$ significance test, which is significantly positively correlated with the export scale of Chinese cultural products. It is basically consistent with the above, indicating that the estimation results in this paper are robust.

\section{Conclusions and Revelation}

This paper takes the panel data of China's export core cultural products from 43 countries in 1995-2016 as a sample, and analyzes the influence of language learning platform on the internationalization of Chinese cultural industry from the perspective of Confucius Institutes. The study found that, in general, the Confucius Institute played an active role in promoting cultural exchanges and disseminating Chinese traditional culture, which was conducive to promoting Chinese enterprises' exports of cultural products. At the same time, there is obvious heterogeneity in this promotion. The specific manifestations are as follows: 
1) The host culture closed to Chinese culture has a good cultural atmosphere for the development of Confucius Institutes, and the Confucius Institute reduces the negative effects of cultural differences. The effect is more obvious, and the promotion of cultural trade is more significant. When the cultural differences between the two countries are large, the Confucius Institute faces more difficulties in carrying out cultural exchanges, which leads to a decline in the promotion effect of Confucius Institutes on the export of Chinese cultural products. 2) The establishment of the Confucius Institute has an intercontinental difference in promoting the internationalization of the cultural industry. For the host countries of Asia and Europe, the promotion of this cultural exchange is most evident, followed by promotion in South America and in North America. This paper has two suggestions:

Firstly, due to the intercontinental differences in the distribution and effects of the Confucius Institutes, the future distribution and co-organization of Confucius Institutes should be more scientifically planned for their global distribution. In areas where the Confucius Institutes have a better effect on cultural trade, such as the host countries of Asia, Europe and South America, the size of the Confucius Institute can be appropriately expanded, so that China's resources in foreign cultural exchanges can better serve the international operation of cultural enterprises.

Secondly, when selecting relevant target markets for the export of Chinese cultural products, relevant enterprises can refer to the promotion role of Confucius Institutes on cultural trade, and consider countries or regions that promote more effective effects as export cultural products to destination markets, so as to avoid bilateral cultural distances and benefit the internationalization of cultural enterprises.

\section{Conflicts of Interest}

The author declares no conflicts of interest regarding the publication of this paper.

\section{References}

[1] Xie, M. (2017) Research on the Investment Effect of Cultural "Going Global": Data from 1326 Confucius Institutes Worldwide. International Trade Issues, No. 1, 39-49.

[2] Shao, J. and Wu, X. (2014) Cultural Discount, Market Size and Export of Chinese Cultural Products. International Business (Journal of University of International Business and Economics), No. 3, 119-128.

[3] Wang, H. (2014) Measurement of the Cost of Export Trade of Creative Products in China and Testing of Influencing Factors. International Trade Issues, No. 10, 132-143.

[4] Melitz, J. (2008) Language and Foreign Trade. European Economic Review, 52, 667-699. https://doi.org/10.1016/j.euroecorev.2007.05.002

[5] Disidier, A.C., Tai, S.H.T., Fontagne, L. and Maye, T. (2010) Bilateral Trade of Cultural Goods. Review of World Economic, 145, 575-595. 
https://doi.org/10.1007/s10290-009-0030-5

[6] Eichengreen, B. and Irwin, D.A. (1998) The Role of History Bilateral Trade Flow. University of Chicago Press, Chicago.

[7] Lian, D. (2014) The Economic and Trade Effect of Confucius Institute. Nanjing University Publishing, Nanjing.

[8] Xie, M., Wang, T. and Cui, R. (2017) Can China's Cultural Output Promote Foreign Direct Investment?-Based on the Empirical Test of the Development of Confucius Institutes. Economics (Quarterly), No. 4, 1399-1420.

[9] An, Y., Yu, X. and Zeng, Y. (2016) The Influence of Language and Culture Promotion Organizations on the Trade of Cultural Products-Taking Confucius Institute as an Example. International Economic Cooperation, No. 12, 81-86.

[10] Kogut, B. and Singh, H. (1988) The Effect of National Culture on the Choice of Entry Mode. Journal of International Business Studies, 19, 411-432. https://doi.org/10.1057/palgrave.jibs.8490394

[11] Hofstede, G.H. and Minkov, M. (2010) Cultures and Organizations: Software of the Mind. 3rd Edition, McGraw-Hill, London. 